\title{
ON-FARM PERFORMANCE ASSESSMENT OF IRRIGATION WATER MANAGEMENT IN THE NILE DELTA OF EGYPT
}

\author{
Doaa E. El-Agha ${ }^{1}$, Mohammed M. Salama ${ }^{2}$, Ashraf M. Ghanem ${ }^{2}$ \\ ${ }^{1}$ Ministry of Water Resources and Irrigation, Egypt \\ ${ }^{2}$ Irrigation and Hydraulics Dept., Faculty of Eng. , Cairo University, Egypt
}

\begin{abstract}
As the agricultural sector is the largest consumer of water in Egypt. Achieving efficient irrigation and drainage systems is becoming essential to meet future demands. This papers highlights the importance of improving the on- farm irrigation water management in old lands of the Nile Delta of Egypt in order to achieve saving of water. A study area namely Bahr Nemra command area (4079ha) was selected to assess the performance of irrigation water management at the on-farm field level for the year 2008-2009. A set of fields were assessed in this study by selecting three fields irrigating directly from the branch canal and representing the head, middle and tail in addition to three fields along a mesqa feeding from the head of the branch canal and three fields along a mesqa feeding from the end of the selected branch canal. All the selected fields were cultivating rice for the summer season and wheat for the winter season to enable comparison. The on-farm application efficiency was calculated, it varied from $46 \%$ to $85 \%$ for rice fields and from $54 \%$ to $94 \%$ for wheat fields. Also, the adequacy was assessed through comparing the amount of the irrigation water applied by farmer per unit area with the irrigation water requirements for each field. The results indicated that farmers tend to over-irrigate their lands. Moreover, the values of land productivity varied from 7.14 to 9.22 ton/ha for rice fields and from 4.8 to 8 ton/ha for wheat fields.
\end{abstract}

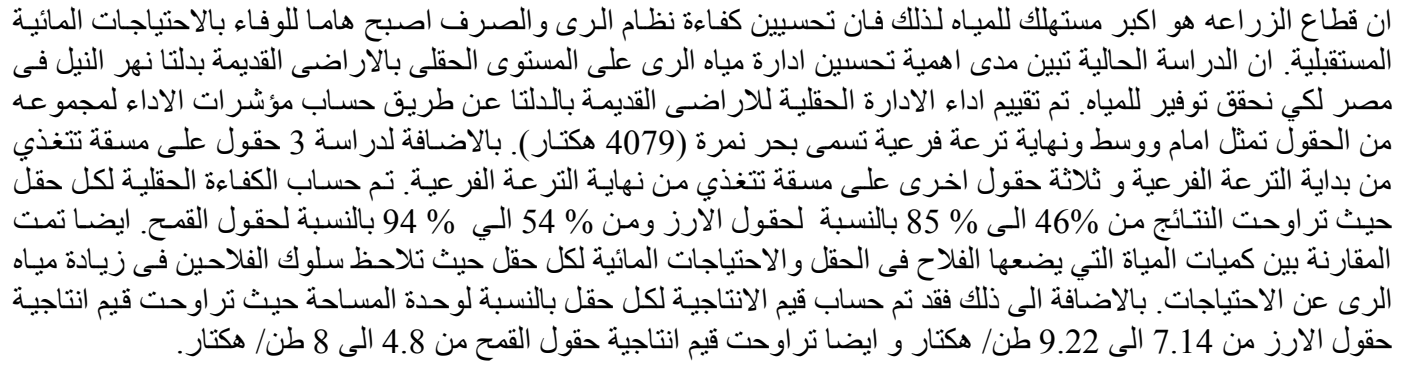

Keywords: Performance, on-farm, indicators, irrigation efficiency, adequacy, productivity

\section{INTRODUCTION}

Water scarcity is a growing global problem challenging sustainable development and expansion of cultivated areas to meet increasing food requirements. Egypt is one of the countries facing great challenges, due to its limited water resources represented mainly by its fixed share of the Nile water, and its aridity which is the general characteristic of the country. Because of population growth, the per capita share of water has dropped dramatically to less than $1000 \mathrm{~m}^{3} / \mathrm{capita}$ which, by international standards, is considered the water poverty limit. The value is expected to drop further to $500 \mathrm{~m}^{3} /$ capita in the year 2025 [1].
Achieving water savings in existing uses through increases in water use efficiency in agriculture has been suggested as the most readily available path to meet future demands while satisfying both current and future needs. Poor management has been cited as the most frequent cause of inefficient water use in irrigation schemes [2]. Improving how water is managed within irrigation and drainage systems is a main key for real saving of water. 
Doaa E. El-Agha, Mohammed M. Salama, Ashraf M. Ghanem, "On-farm Performance Assessment ..."

\section{STUDIED AREA}

Bahr Nemra branch canal command area was chosen to assess the performance at the on-farm level. Bahr Nemra canal is an earthen distributary canal. It is a part of El-Gharbeya irrigation directorate and located in the right side of Meet Yazid canal at km 19.600 as shown in Fig. 1. The canal serves an area of about 4079 ha. It has a length of about $11.900 \mathrm{~km}$. Design bed widths vary between $7 \mathrm{~m}$ and $1.5 \mathrm{~m}$. Average bed slope is about $7 \mathrm{~cm} / \mathrm{km}$. The whole canal is operated on rotational basis, where a two-turn rotation system is practiced during the summer season ( 5 days on and 5 days off) and a three turn rotation system is practiced during the winter season (5 days on and 10 days off). The control structure at the head of the canal is a Fahmy
Haneen type gate. The main summer crops in the command area are rice and cotton. In winter the main crops are clover and wheat. Bahr Nemra canal command area is served by two main drains, namely Samatay drain and El-Segaeya drain.

To study the performance at the on farm field level, sample fields were selected to measure performance indicators. Along the branch canal (Bahr Nemra) three fields were chosen which are located at the head, middle and tail and irrigate directly from the branch canal. In addition three fields (head, middle and tail) were selected along mesqa El-Bahawat at the head of the branch canal and also three fields (head, middle and tail) along mesqa Sera at the end of the branch canal. The description of each field is shown in table (1).

Table 1, Description of the selected fields for the on-farm study

\begin{tabular}{|c|c|c|c|c|c|c|c|}
\hline \multirow[b]{2}{*}{ Name } & \multirow[b]{2}{*}{ Location } & \multicolumn{3}{|c|}{ Summer season 2008} & \multicolumn{3}{|c|}{ Winter season 2008-2009 } \\
\hline & & $\begin{array}{r}\text { Area Served } \\
\text { (ha) }\end{array}$ & $\begin{array}{r}\text { Type of } \\
\text { crop }\end{array}$ & $\begin{array}{r}\text { pump } \\
\text { capacity } \\
(\text { Liter/sec) }\end{array}$ & $\begin{array}{r}\text { Area } \\
\text { Served } \\
\text { (ha) }\end{array}$ & $\begin{array}{r}\text { Type of } \\
\text { crop }\end{array}$ & $\begin{array}{r}\text { pump } \\
\text { capacity } \\
\text { (Liter/sec) } \\
\end{array}$ \\
\hline \multirow{3}{*}{$\begin{array}{r}\text { Direct Bahr } \\
\text { Nemra }\end{array}$} & Head & 1.01472 & Rice 101 & 40 & 0.21 & Wheat 61 & 40 \\
\hline & Middle & 0.63 & $\begin{array}{l}\text { Rice } \\
\text { Hageen }\end{array}$ & 45 & 0.525 & $\begin{array}{l}\text { Wheat } \\
\text { Gemiza } 9\end{array}$ & 40 \\
\hline & Tail & 0.63 & Rice 78 & 40 & 0.42 & Wheat 63 & 50 \\
\hline \multirow{3}{*}{$\begin{array}{c}\text { El-Bahawat } \\
\text { Mesqa at the } \\
\text { Head of Bahr } \\
\text { Nemra }\end{array}$} & Head & 2.1 & Rice 101 & 40 & 0.21 & Wheat 93 & 40 \\
\hline & Middle & 2.52 & Rice101 & 40 & 2.52 & Wheat 93 & 45 \\
\hline & Tail & 1.68 & Rice 101 & 40 & 0.21 & Wheat 93 & 45 \\
\hline \multirow{3}{*}{$\begin{array}{r}\text { Sera Mesqa at } \\
\text { the Tail of Bahr } \\
\text { Nemra }\end{array}$} & Head & 1.68 & Rice 78 & 45 & 0.21 & Wheat 93 & 40 \\
\hline & Middle & 0.42 & Rice 101 & 40 & 1.47 & Wheat 93 & 45 \\
\hline & Tail & 1.26 & Rice 101 & 45 & 0.42 & Wheat 93 & 40 \\
\hline
\end{tabular}

\section{DATA USED FOR THE STUDY}

The data collected was for two seasons of year 2008-2009 summer and winter. The pumps that farmers used for irrigation were calibrated. The data of irrigation were recorded (date of every irrigation, time and duration of irrigation, cultivated area). After the end of the summer and winter seasons the productivity data of each field was collected. Data about the ground water level and salinity of installed observation wells in the study area was collected.
Metrological data from the nearest weather station (Sakha weather station) for year 2008-2009 was collected to calculate the irrigation water requirements for rice and wheat fields using Penman Montieth equation. The procedures used for the calculation of crop water requirements and irrigation requirements were based on methodologies presented in Irrigation and Drainage FAO papers Nos. 56 and 33. 


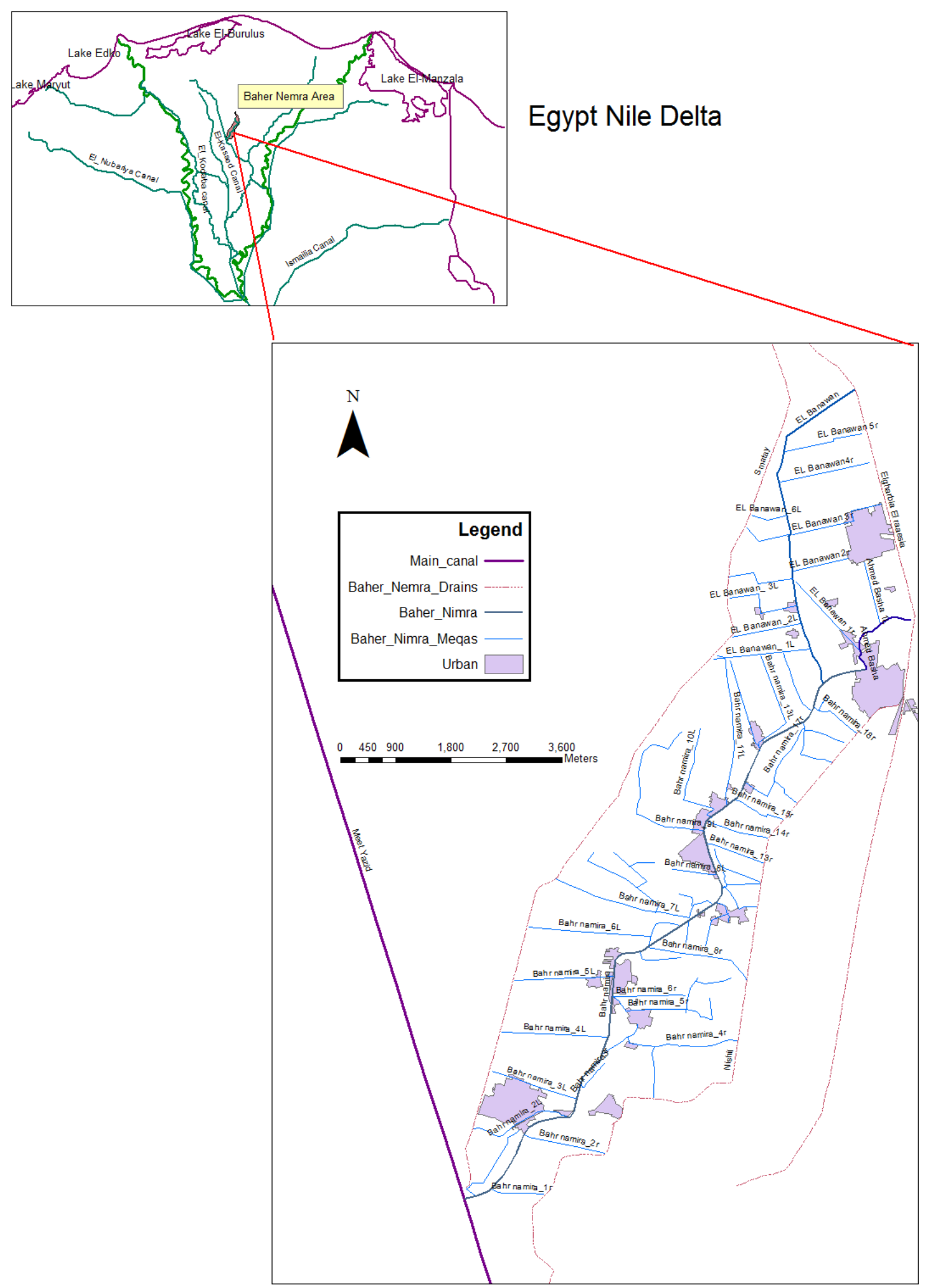

Baher Nemra Command Area

Fig. 1 Location map of Bahr Nemra branch canal and the selected studied fields 


\section{SELECTED INDICATORS}

The performance assessment was measured through the use of selected indicators. The analysis of these indicators then informed us on the level of performance of irrigation water management. Three criteria were assessed in this study; efficiency, adequacy and productivity. Three performance indicators were calculated as follows;

\subsection{Field Application Efficiency}

This indicator measures the efficiency at the on-farm level. It is defined as [3]

\section{Field application efficiency}

$$
=\frac{\text { Volume of water needed by crop }\left(E T_{p}-P_{e}\right)}{\text { Volume of water supplied to fields }}
$$

[Dimensionless]

Where; $\mathrm{ET}_{\mathrm{p}}$ is the potential evapotranspiration and $\mathrm{P}_{\mathrm{e}}$ is the precipitation on the gross command area.

The numerator of this indicator is defined by [5] as the volume of irrigation water needed and made available to avoid undesirable stress in the crops throughout the considered part of the growing cycle in terms of $\mathrm{m}^{3} / \mathrm{ha}$. The volume of water delivered to the field is expressed in terms of $\mathrm{m}^{3} /$ ha or in terms of water depth. The numerator equals the potential evapotranspiration by the irrigated crop minus the effective part of the precipitation $\left(\mathrm{ET}_{\mathrm{p}}-\mathrm{P}_{\mathrm{e}}\right)$. The value of $\left(\mathrm{ET}_{\mathrm{p}}-\mathrm{P}_{\mathrm{e}}\right)$ is entirely determined by the crop, the climate and the interval between water applications. Hence, the value of the field application efficiency varies with the actual volume of irrigation water delivered to the field by farmers.

\subsection{Water Application per Unit Area}

The water application per unit area indicator was proposed by the World Bank and defined in [5] as the ratio between irrigation water supply and the total command area. It is defined as:

Water Application per Unit Area $=\frac{\text { Total Irrigation Water Supply }\left(\mathrm{m}^{3}\right)}{\text { Total Command Area }(\mathrm{ha})}$

This indicator can be compared with the value of irrigation water requirement per unit area to measure adequacy of irrigation water supply.

\subsection{Productivity per Unit Area}

The productivity indicators are related to the output from the irrigation system in response to the input added to the system. There are several indicators which express the productivity performance level. These indicators provide the basis for comparison of irrigated agriculture performance. In this paper the productivity per unit area was calculated.

It is a ratio, which relates the crop yield with the cropped area as defined [6]:

$$
\text { Productivity per unit area }(\mathrm{kg} / \mathrm{ha})=\frac{\text { Yield of Harvested Crop }[\mathrm{kg}]}{\text { Cropped Area }[\mathrm{ha}]}
$$

\section{RESULTS AND DISCUSSIONS}

Three indicators were chosen to study the performance of water management at on-farm field level. First, the on-farm application efficiencies were calculated as improvement of on-farm irrigation is important not only to enhance the overall irrigation efficiency of the irrigation but also to boost the crop water productivity; Second, water application per unit area which is compared with irrigation water requirements at each field to measure the adequacy of irrigation water applied; and third, the productivity per unit area to assess the output of each field. The results and discussion of the selected indicators are introduced in the following sections.

\subsection{Field Application Efficiency}

The results of the field application efficiency for the rice fields varied from $46 \%$ to $85 \%$ as shown in Fig. 2. On the other hand the results for wheat fields varied from $54 \%$ to $94 \%$ as shown in Fig. 3. It was noticed that the field application efficiency values were not affected by the location of the farm along the mesqa or the branch canal. The application rate and period differs mainly according to farmers' behavior. There are other factors affecting the application efficiency such as infiltration characteristics (soils, wetted area, water quality, compaction, the application technique, field layout, land leveling, etc.).

The results of on-farm application efficiency indicated a large variation between fields, thus there is an opportunity for improving this indicator through enhancing the low field application efficiency values.

The overall irrigation efficiency $\left(\mathrm{E}_{\mathrm{p}}\right)$ of an irrigation system is divided into three components: conveyance efficiency $\left(\mathrm{E}_{\mathrm{c}}\right)$, field channel efficiency $\left(E_{b}\right)$, and field application efficiency $\left(E_{a}\right) . \quad E_{c}$ is the ratio of water received at the inlet to a block of fields to water released at the head works. $E_{b}$ is the ratio of water received at the field inlet to water received at the inlet of the block of fields, and Ea is the ratio of water used by the crop to water received at the field 
inlet [7]. Conveyance and field channel efficiencies are sometimes combined as distribution efficiency $\left(E_{d}\right)$, where $E_{d}=E_{c} \times E_{b}$. Furthermore, $E_{p}=E_{a} \times E_{b}$ $x E_{c}$ [7], which implies that the overall irrigation efficiency will not be improved if the on-farm application efficiency stayed low.

Working at one level of the irrigation system with a target of saving water will be outbalanced by efficiency losses elsewhere. All the previous and current activities for old land irrigation system improvement in Egypt concentrate on increasing only the distribution efficiency through applying continuous flow system at branch canals level, replacing old earthen mesqa by PVC pipelines and later replacing earthen marwa by PVC pipelines. For increasing the overall irrigation efficiency the onfarm application efficiency should be improved at the same time with the distribution efficiencies. That improvement can be established through improved on-farm management activities such as land leveling, agronomic practices, the modifying of the cultivation methods and also training farmers. The average values of the field application efficiency was 0.7 for rice fields and 0.77 for wheat fields. Improvement projects should have a target value of field application efficiency to enable achieving saving of water. According to the results of this study, the target value of field application efficiency can reach 0.8 by applying improved on-farm water management activities.

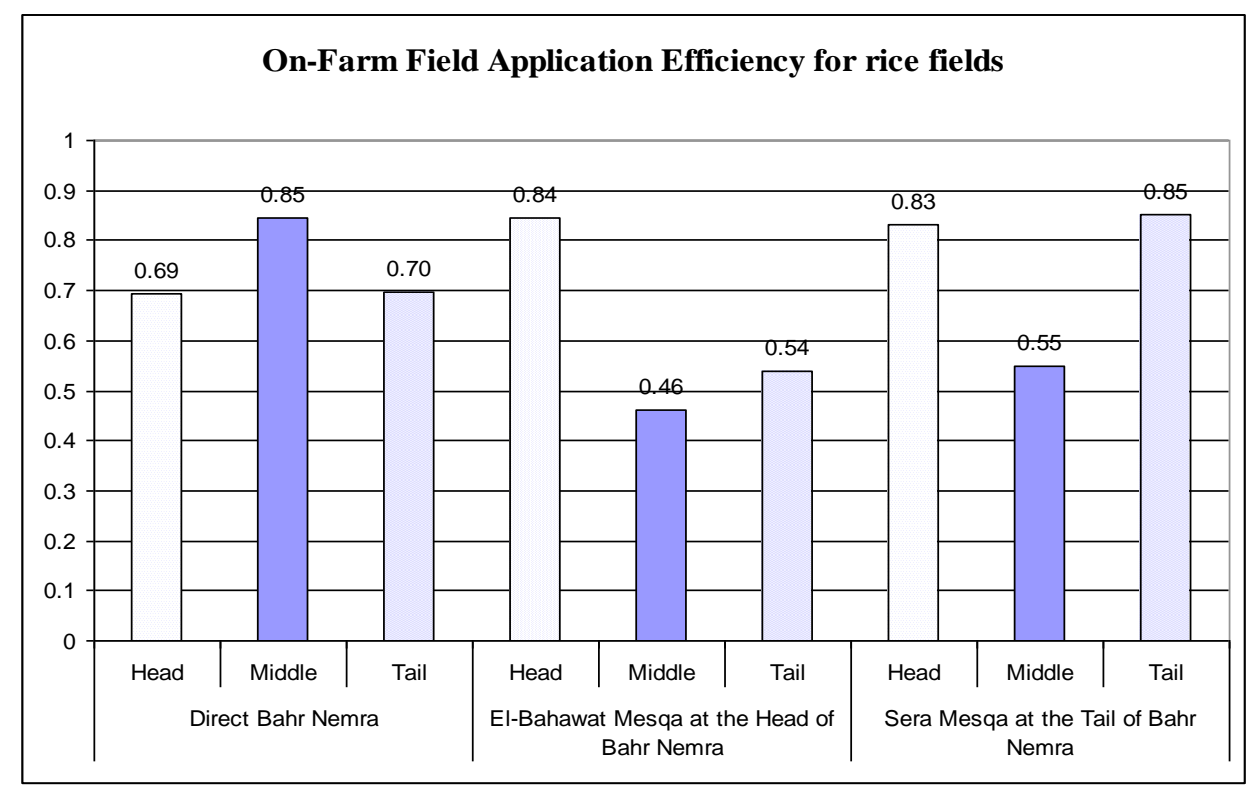

Fig. 2 On-Farm field application efficiency for rice fields

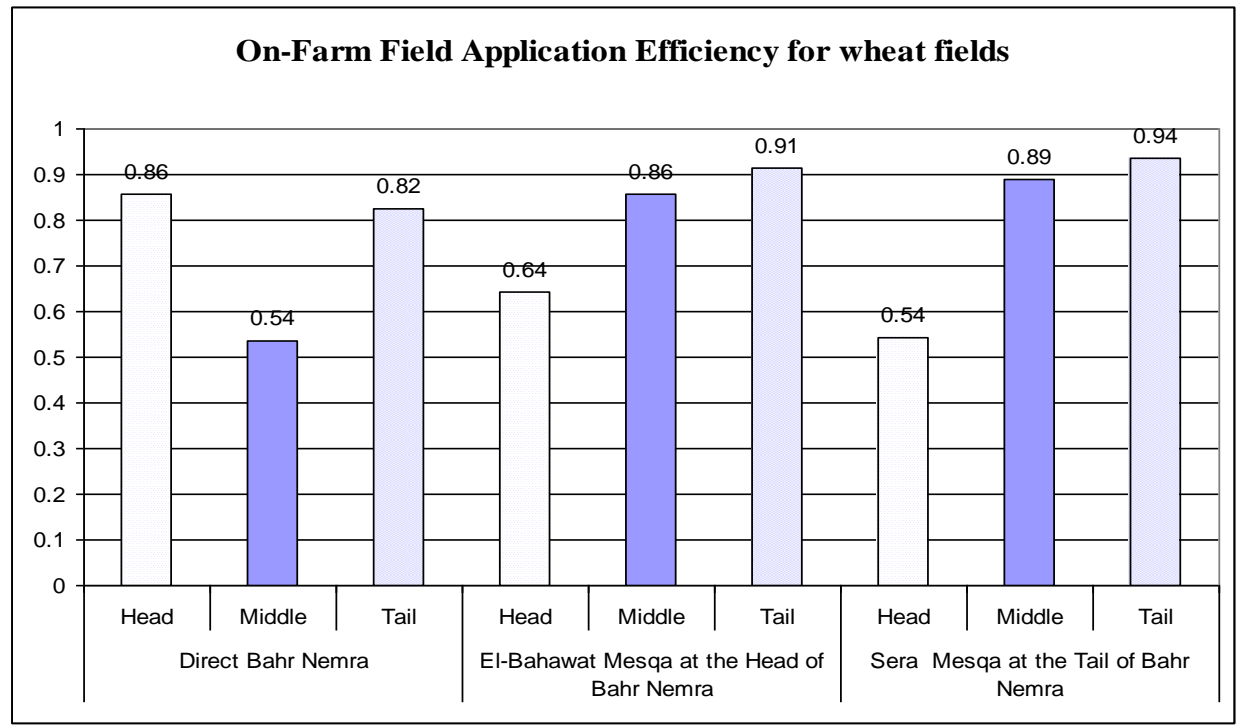

Fig. 3 On-Farm field application efficiency for wheat fields 
Doaa E. El-Agha, Mohammed M. Salama , Ashraf M. Ghanem, "On-farm Performance Assessment ..."

\subsection{Irrigation Water Applied per Unit Area $\left(\mathrm{m}^{3} / \mathrm{ha} /\right.$ season$)$}

Irrigation water applied per unit area was calculated and compared for the studied fields along mesqa and along branch canal. This indicator when compared with the irrigation water requirements measures the over-irrigation practices along canals and mesqas.

The values of irrigation water applied per unit area in rice fields varied from $14682 \mathrm{~m}^{3} / \mathrm{ha} /$ season to $27057 \mathrm{~m}^{3} /$ ha/season. The irrigation water requirements per unit area of rice $\left(\mathrm{ET}_{\mathrm{p}}+\right.$ leaching requirements + special practices needs) was $13887 \mathrm{~m}^{3} / \mathrm{ha} /$ season as shown in Fig. 4. On the other hand, the values of irrigation water supply in wheat fields varied from $3771 \mathrm{~m}^{3} / \mathrm{ha} /$ season to $6583 \mathrm{~m}^{3} / \mathrm{ha} / \mathrm{season}$ and the irrigation water requirements per unit area for wheat fields $\left(E_{\mathrm{p}}-\mathrm{P}_{\mathrm{e}}\right.$ - Gw + LR) was $3066 \mathrm{~m}^{3} / \mathrm{ha} /$ season as shown in Fig. 5. It was noticed that all fields satisfied their requirements of irrigation and some fields had over-irrigation practices. Therefore, there is a need for reducing the amount of irrigation water that farmers apply in their fields in order to enhance the water use efficiency and reduce water losses to drainage and saline sinks.

\subsection{Productivity per unit area (ton/ha)}

Farmers are interested in the returns to their farming enterprise, and less concerned about overall returns to the resource base (water). So, comparing the productivity per unit area would be important to study the opportunities of increasing farmers' income through enhancing the productivity of lands and satisfying farmers' implications and attracting them to participate in the water management improvement. Land productivity indicator proposed by [6] quantifies the values of crop yield per unit area.

Rice productivity per unit area varied from 7.14 to 9.22 ton/ha with an average of 8.3 ton/ha as shown in Fig. 6. Wheat productivity per unit land varied from 4.8 to 8.1 ton/ha with an average of 6.6 ton/ha as shown in Fig. 7.

The value of land productivity of wheat fields showed more variation than rice fields. It was noticed that the variation is not related to the amount of irrigation water applied by farmers to each field. The factors affecting the values of productivity here were agronomic factors like the variety of seeds for each crop, fertilizers and the cultivation methods.

The collected data of soil salinity and water table for Bahr Nemra command area at winter season showed high variation. The values of soil salinity varied from 1.64 to $10.85 \mathrm{mmhos} / \mathrm{cm}$ and the depth of water table varied from 0.65 to $1.25 \mathrm{~m}$. Theoretically, wheat doesn't suffer greatly from salt induced yield depression if the soil electrical conductivity remains below $6 \mathrm{mmhos} / \mathrm{cm}[8]$.

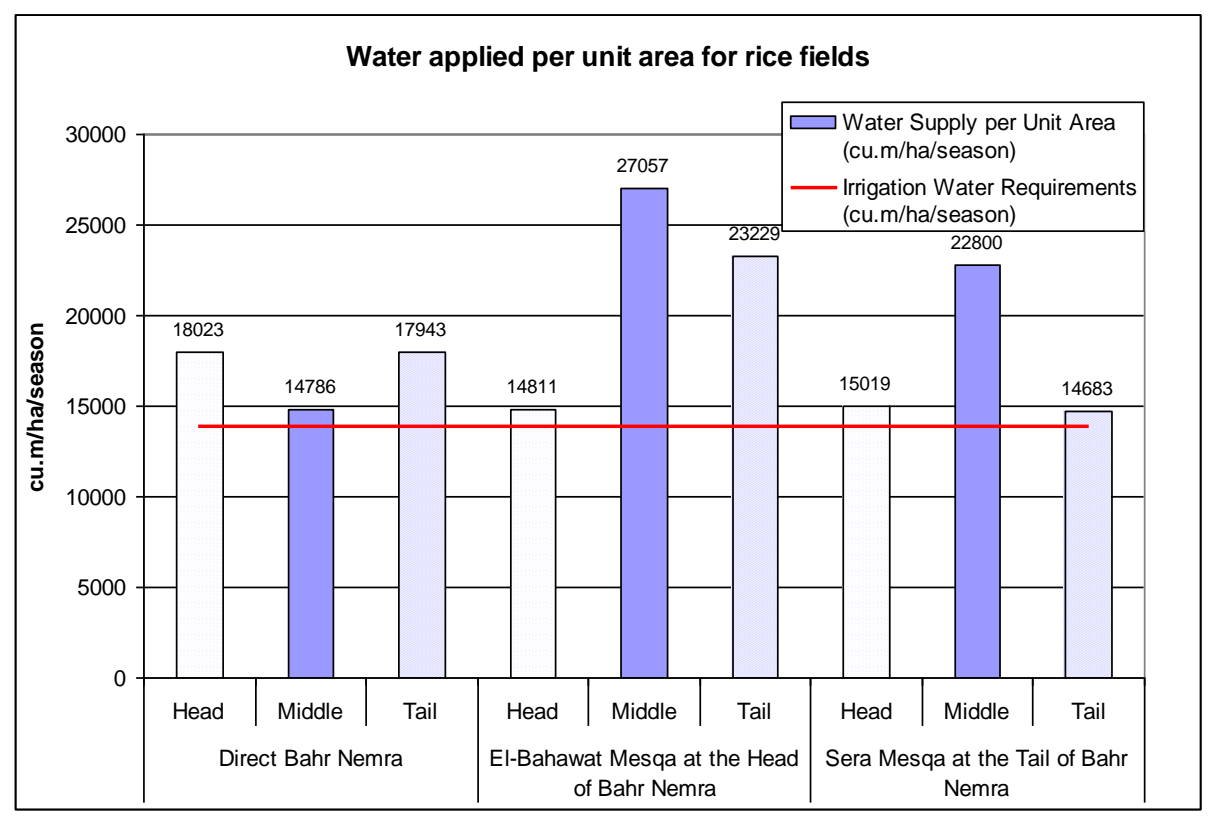

Fig. 4 Water applied per unit area for rice fields 
Doaa E. El-Agha, Mohammed M. Salama, Ashraf M. Ghanem, "On-farm Performance Assessment ..."

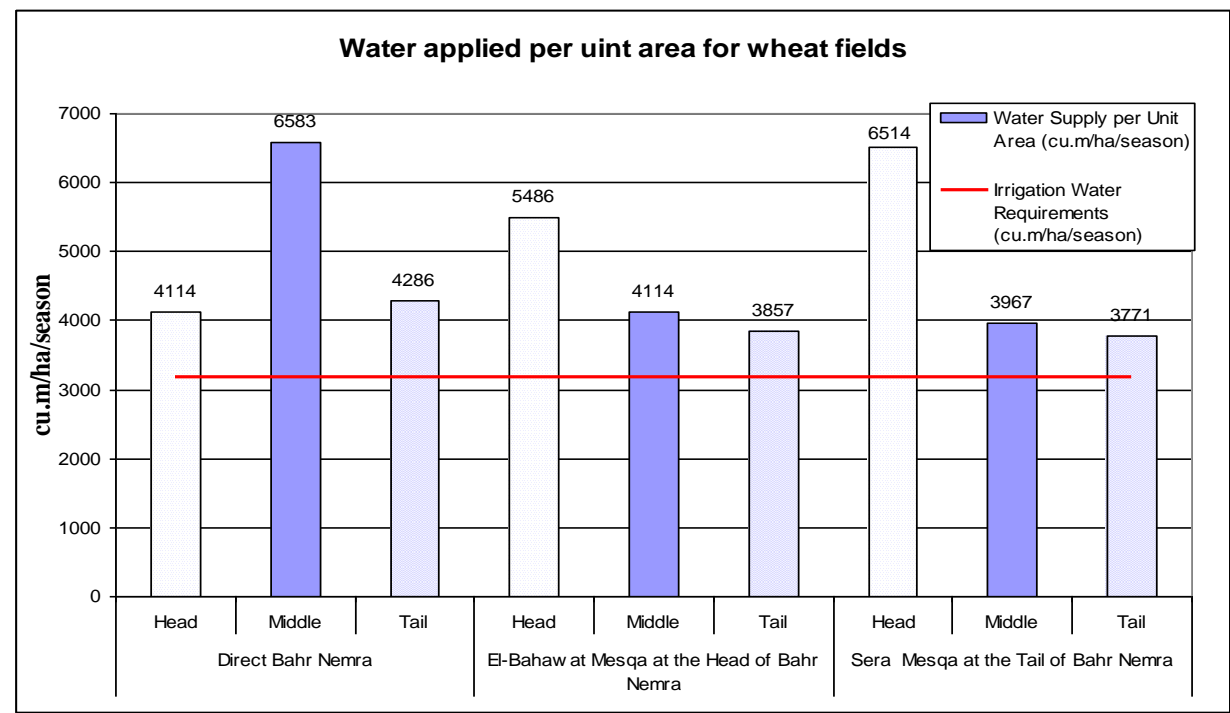

Fig. 5 Water applied per unit area for wheat fields

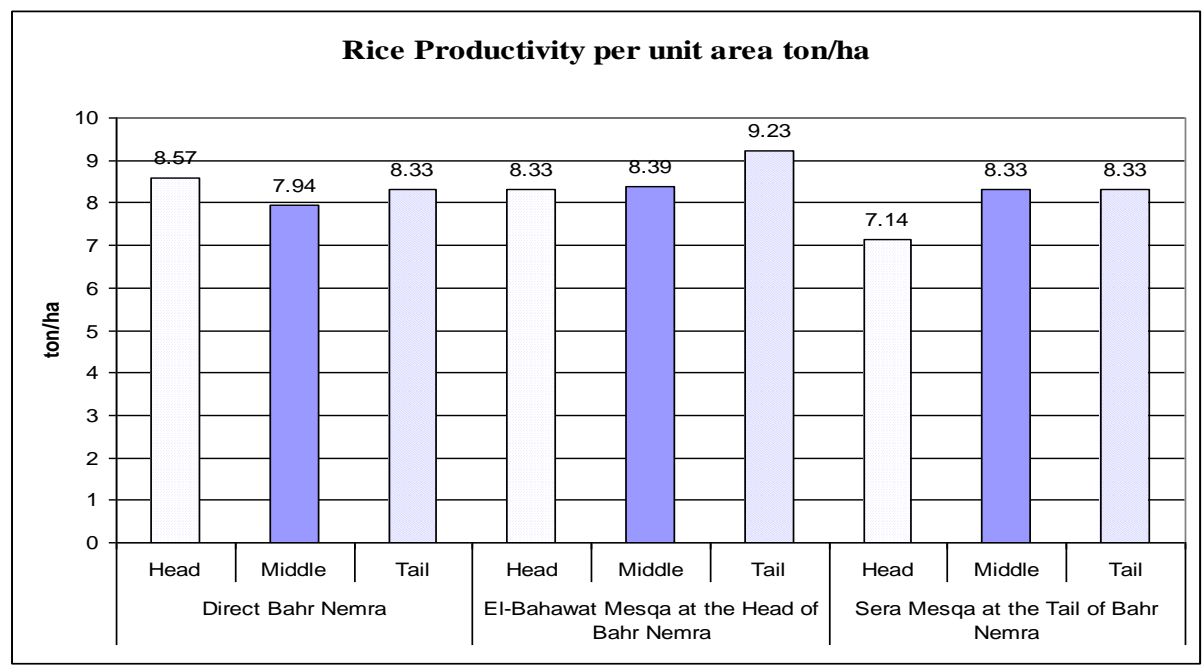

Fig. 6 Rice productivity per unit area (ton/ha)

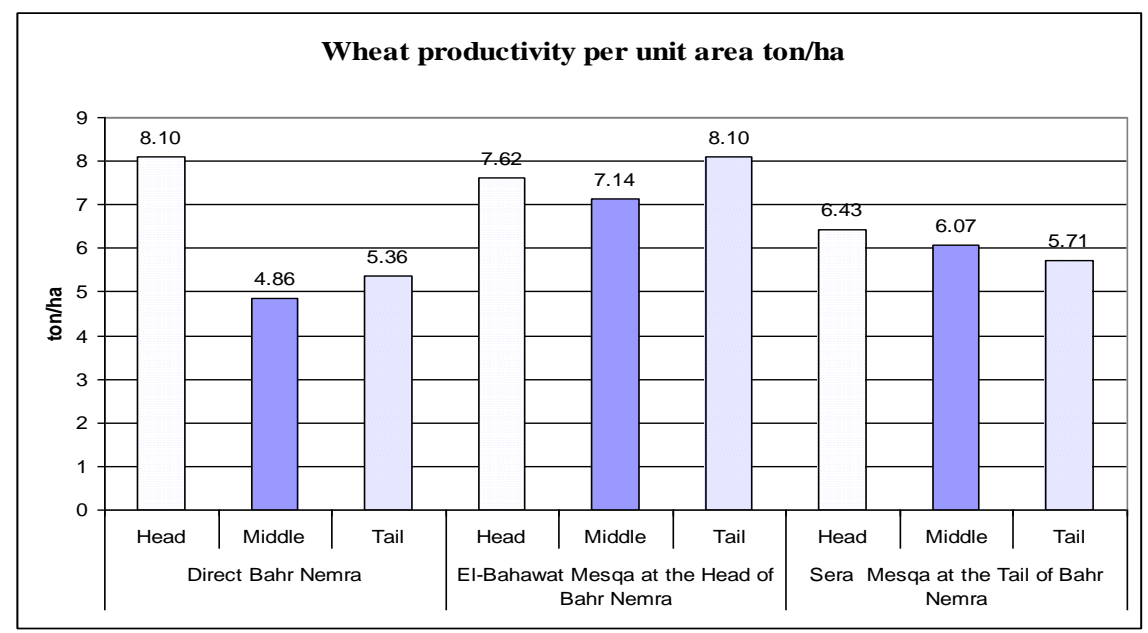

Fig. 7 Wheat productivity per unit area (ton/ha) 
Doaa E. El-Agha, Mohammed M. Salama, Ashraf M. Ghanem, "On-farm Performance Assessment ..."

\section{CONCLUSIONS}

According to the performance assessment study at the on-farm level of Bahr Nemra command area, the following can be concluded;

1. On-farm field application efficiency for rice fields varied from $46 \%$ to $85 \%$ and for wheat fields varied from $54 \%$ to $94 \%$. These varied values indicated an opportunity for improving on farm application efficiency through enhancing the low values. It was noticed that the values depended on the farmers' behavior which can be enhanced by training farmers and applying onfarm water management activities such as land leveling by laser and applying improved agronomic practices at field level.

2. Water application per unit area indicator values varied from $14682 \mathrm{~m}^{3} / \mathrm{ha} /$ season to $27057 \mathrm{~m}^{3} / \mathrm{ha} / \mathrm{season}$ for rice fields, while the irrigation water requirements per unit area of rice were $13887 \mathrm{~m}^{3} / \mathrm{ha} /$ season. On the other hand, the values of irrigation water supply in wheat fields varied from $3771 \mathrm{~m}^{3} / \mathrm{ha} /$ season to 6583 $\mathrm{m}^{3} / \mathrm{ha} /$ season and the irrigation water requirements per unit area for wheat fields were $3066 \mathrm{~m}^{3} / \mathrm{ha} / \mathrm{season}$. These values indicate that all fields had satisfied their requirements and some fields had over-irrigation. Thus the need for adopting water saving strategies at on-farm levels is becoming essential to reduce water application by farmers at their fields.

3. Rice productivity per unit area varied from 7.14 to 9.22 ton/ha and the wheat productivity per unit area varied from 4.8 to 8 ton/ha. It was found that the main factors that affected the land productivity values were agronomic factors like the varieties and type of seeds cultivated and also the irrigation methods that farmers used. Meanwhile there was noticeable variation of productivity between fields especially wheat fields, which indicated the opportunity for improving land productivity.

\section{REFERENCES}

[1] NWRP, "National Water Resources Plan 2017" Ministry of Water Resources and Irrigation, Cairo, Egypt, January, 2005.

[2] Jensen, M.E., Rangeley, W.R. and Dielerman, P.J., "Irrigation Trends in World Agriculture" Irrigation Agricultural Crops, Agronomy Monograph 30, ASA, Wisconsin, USA, 1990, pp 31-67.

[3] ICID, "Standards for the calculation of irrigation efficiencies" ICID Bulletin 27, 1978, pp.91-101.

[4] Bos, M.G., Burton, M.A., and Molden, D.J., "Irrigation and Drainage Performance Assessment" practical guidelines, CABI publishing, British Library, London, UK, 2005.

[5] Burt, C.M. and Styles, S.W., "Modern Water Control and Management Practices in Irrigation - Impact on Performance" Water Report No. 19, Food and Agriculture Organization of the United Nations, Rome, 1999.

[6] Molden, D.J., Sakthivadivel, R., Perry, C.J., de Fraiture, C. and Kloezen, W.H., "Indicators for comparing performance of irrigated agricultural systems." Research report 20. International Irrigation Management Institute, Colombo, SriLanka, 1998.

[7] Doorenbos, J. and Pruitt, W.O., "Crop Water Requirement" Irrigation and Drainage Paper 24. Food and Agriculture Organization of the United Nations, Rome, 1979, pp.118.

[8] Bastiaanseen, W.G.M, Molden, D.J., Thiruvengadachari, S., Smit, A.A.M., Mutuwatte, L., and Jayasinghe, G., " Remote Sensing and hydrological Models for Performance Assessment in Sirsa Irrigation Circle, India" International Water Management Institute Research Report No. 27, Colombo, SirLanka, 1999, pp. 12. 